\title{
A 360-Degree Surgical Approach for Correction of Cervical Kyphosis and Atlantoaxial Dislocation in the Case of Larsen Syndrome
}

\author{
${ }^{1}$ Department of Neurosurgery, National Institute of Mental Health \\ and Neurosciences (NIMHANS), Bangalore, India \\ 2Department of Neurosurgery, Sanjay Gandhi Postgraduate \\ Institute of Medical Sciences, Lucknow, Uttar Pradesh, India
}

Harsh Deora ${ }^{1}$ Suyash Singh ${ }^{2}$ Jayesh Sardhara ${ }^{2}$ Sanjay Behari

\begin{abstract}
Address for correspondence Jayesh Sardhara, MS, MCh, Department of Neurosurgery, Sanjay Gandhi Postgraduate Institute of Medical Sciences, Lucknow, UP, India (e-mail: jayeshsardhara83@gmail.com).
\end{abstract}

J Neurosci Rural Pract 2020;11:196-201

\begin{abstract}
Larsen syndrome is chronic debilitating disease that presents with multiple joint dislocations and severely affects the cervical spine in the form of cervical kyphosis and atlantoaxial dislocation. Children usually present in early with a myriad of deficits, compressive myelopathy being the most common. In addition to a bony compression, there is sometimes a soft tissue component, which is seldom addressed. We present here a case of atlantoaxial dislocation with cervical kyphosis due to Larsen syndrome,

Keywords

- cervical kyphosis

- atlantoaxial dislocation

- Larsen syndrome and along with our previous experience on syndromic atlantoaxial dislocations, we try to define an algorithm for the treatment approach of these onerous challenges. The importance of early intervention is also emphasized with a literature review of similar cases. In addition to the obvious physical damage, early intervention can also avoid the more sinister socioeconomic face of this debilitating disease.
\end{abstract}

\section{Introduction}

In 1950, Larsen et al described the first series of cases with distinctive facial features, multiple joint dislocations, and spinal anomalies. ${ }^{1-12}$ There is also a risk of dramatic cervical instability and sudden neurological deficit and death, as reported by Larsen himself. Since 1950, several authors have reported similar findings and yet a consensus regarding timing of correction, surveillance, pre- and postoperative bracing, and even the preferred surgical approach is missing. This is due to the wide spectrum of presentation and difference in severity at initial clinical evaluation.

Larsen syndrome occurs in 1 in 100,000 newborns, which is caused by mutations in the gene encoding filamin B (FLNB; 603381) on chromosome 3p14 that is important in regulating the structure and activity of the cytoskeleton. ${ }^{13-15}$ We present a case of Larsen syndrome, which was managed, at our institute along with a possible protocol for the management of such cases in the future.

\section{Case Report}

\section{History and Examination}

"Dish face" they used to call him. A 15-year-old boy, studying in eighth grade, right-handed, presented with a prominent

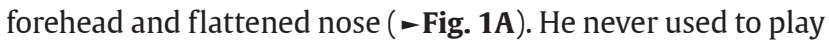
with the other boys, lest he risk getting injured, a lesson he had learned early in his life. They used to ridicule him for his long thin "spider"-like limbs ( - Figs. 1B and C). Social stigma apart, he started noticing that the school bag was getting heavier. It became nearly impossible to walk to school with it. Gradually, feeding oneself became a task. The food would often slip through the fingers like grains of sand. Assistance was needed to drink water or even go to the toilet. Eventually, he was bed ridden for the better part of last month. However, he had retained function of his bladder and bowel, with inability to walk to the toilet. On inquiring from his teachers, they would describe him as a student with an average scholastic performance. 


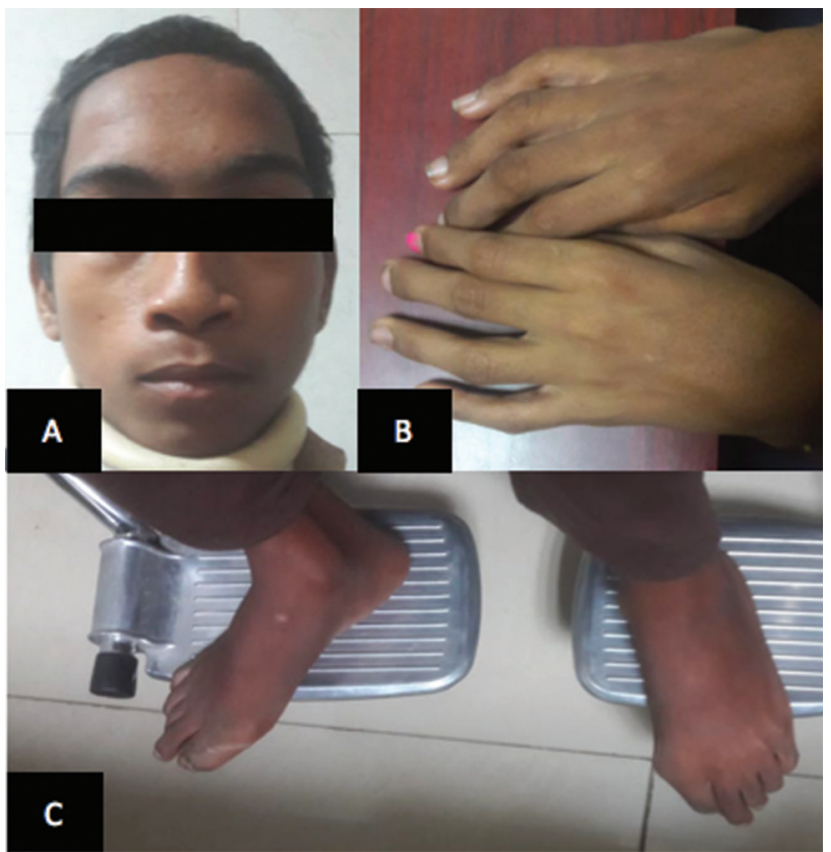

Fig. 1 Clinical photograph of Larsen syndrome with prominent forehead and flattened nose (A) and spider-like limbs (B and $\mathbf{C})$.

On examination, his height was a $150 \mathrm{~cm}$ and weight $40 \mathrm{~kg}\left(\mathrm{BMI}=17.8 \mathrm{~kg} / \mathrm{m}^{2}\right)$. There was a definite kyphotic deformity of the spine without any local tenderness. He was able to lift all four limbs against gravity and had definite signs of myelopathy in the four of exaggerated deep tendon reflexes with upgoing plantars. Handgrip was worse on the right (30-40\%) side than left (50\%). Superficial reflexes were absent with graded sensory loss to all four modalities below C4 dermatome. Single breath count was 7 with a breath holding time of 20 seconds.

Past history was suggestive of multiple fracture dislocations of shoulders and knee often while playing in school after which the child had started to refrain from contact sports. There was no history of consanguinity in the family with birth history being unremarkable apart from the fact the child was home delivered. No history of recent trauma or tuberculosis could be elicited. The history, characteristic facial features, and physical findings were suggestive of a compressive myelopathy due to congenital atlantoaxial dislocation.

$\mathrm{X}$-ray of the cervical spine revealed a gross kyphotic deformity at C6 to C7 and atlantoaxial dislocation. Careful evaluation of computed tomography (CT) of the cervical spine showed kyphotic deformity ( - Fig. 2A, B) due to anterior wedging of $\mathrm{C} 5$ vertebrae. The atlantoaxial joints showed degenerative changes. Magnetic resonance imaging demonstrated significant compression of the cord with signal changes at the craniovertebral junction and minimal retroflexion of the odontoid, although the soft tissue compression anterior to the cervical cord was significant.

\section{Surgical Planning}

There were two major considerations while doing the surgical planning: Soft tissue compressing the cervical cord at the cervicomedullary junction and the kyphosis at C5 to 7 levels. Both of the pathologies were significant and hence a decision was made for a transoral decompression of the soft tissue component followed by posterior fixation, including the two transition zones at craniovertebral junction and C7 to T1 levels. However, since more than three levels were involved a completely anterior approach with C5 corpectomy was abandoned as a single posterior fusion and decompression would deal with all the levels adequately. Since the compression was due to kyphosis and a soft tissue component, without any dislocation, preoperative traction was not considered.

\section{Surgery}

The patient was placed supine with neuromonitoring in the form of motor-evoked potentials and somatosensory potentials. He underwent a transoral-transpharyngeal approach that allowed lateral exposure of roughly 15 to $20 \mathrm{~mm}$ bilaterally off the midline from the inferior clivus to the $\mathrm{C} 3$ body. The anterior arch of $\mathrm{C} 1$ was drilled, laterally up to the lateral margins of the odontoid ( $\sim 15 \mathrm{~mm}$ from midline). Safety margins lie within $11 \mathrm{~mm}$ from the midline at the foramen

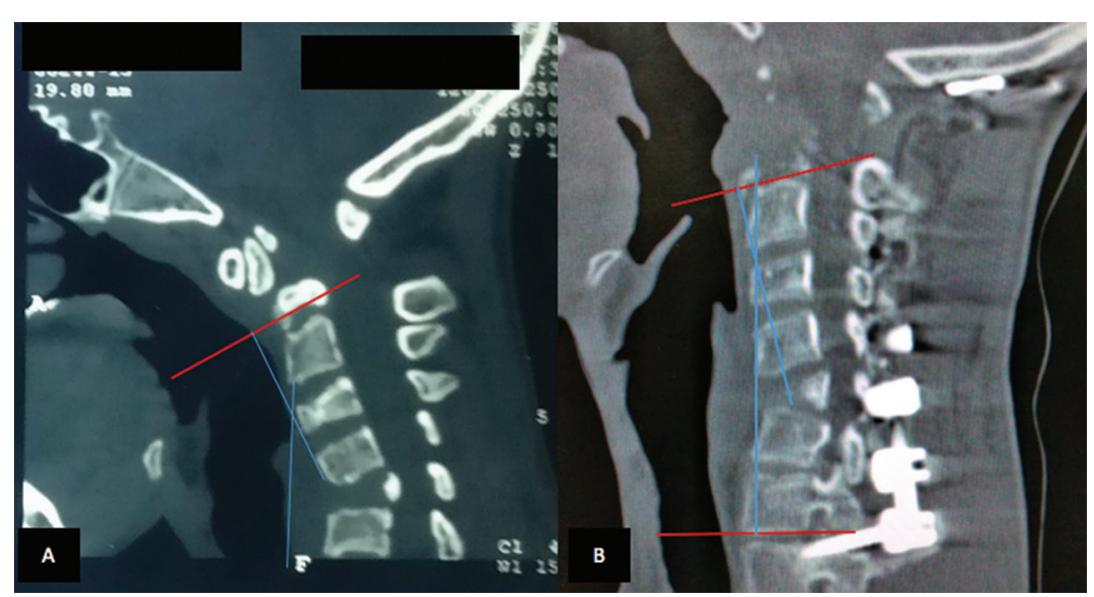

Fig. 2 Plain computed tomographic scan of sagittal section of patient demonstrating improvement in preoperative kyphotic deformity (Cobb angle 27 degrees to postoperative 14 degrees). 


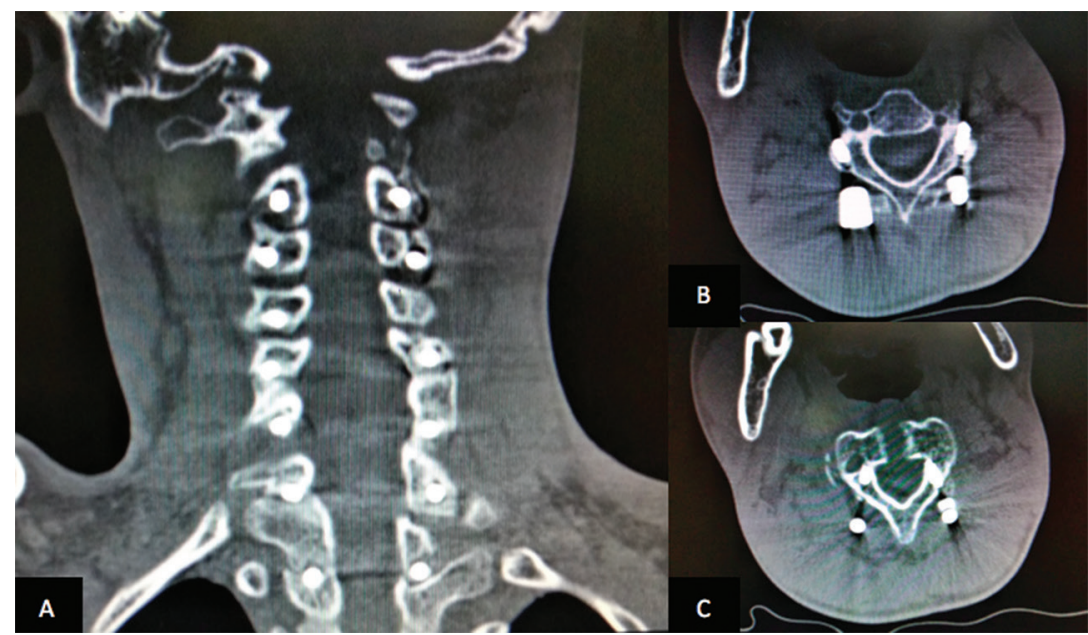

Fig. 3 Postoperative coronal (A) and axial (B, C) computed tomographic scan with posterior stabilization.

magnum, $24 \mathrm{~mm}$ at the atlas, and $14 \mathrm{~mm}$ at the lower border of the axis. Following this the odontoid drilling was done in a top down fashion. This avoided formation of a free-floating fragment of the dens as it was always attached at its base. A thick pannus was seen below the odontoid composed of elastic collagenous tissue and was gradually teased out using nibblers till pulsating dura was visible. After hemostasis, the closure proceeded sequentially using vicryl 2-0 and then monofilament 2-0 suture in an intermittent pattern. Immediate posterior stabilization was done by occipitocervical fixation including $\mathrm{T} 1$. Intraoperative manipulation was done to correct the kyphotic deformity (-Figs. 2 and 3) with the neuromonitoring parameters remaining unchanged throughout.

\section{Postoperative Course}

The patient was transferred to the postoperative intensive care unit and was extubated the next day followed by Ryles tube feeding started on day 2 . He was transferred to the rehabilitation unit, from which he was later discharged neurologically intact with reduced spasticity on day 7 after surgery. Postoperative CT demonstrated complete correction of the deformity (-Fig. 2). Cervical collar was maintained for 3 weeks. Follow-up at 18 months showed excellent recovery of power to $4+/ 5$ with independent ambulation and ability to take care of daily needs with return to school.

\section{Discussion}

Atlantoaxial dislocation is different in this case when compared with other syndromic and nonsyndromic varieties. We have found, in our case, that not only does the bony kyphosis cause compression and myelopathy, but also there was a soft tissue component to the compression. ${ }^{16-18}$ During anterior decompression after removal of the odontoid, there was no dura visible and neither any pulsations were seen. On removal of soft cartilaginous tissue using rongeurs and nibblers, the dura was finally seen and compression relieved. Consequently, to achieve complete decompression of the cord, a 360-degree approach is necessary. Madera et $\mathrm{al}^{14}$ were the first to perform a synchronous anterior decompression and fixation, posterior fusion, and fixation for a case of Larsen syndrome. ${ }^{14}$ On extensive review, there have been 22 cases of surgically treated cervical deformity in patients with Larsen syndrome (-Table 1). The authors have significant previous experience in managing syndromic atlantoaxial dislocation and proposing an algorithmic approach (-Fig. 4) for the management of such cases. , $3,8,9,19$

The treatment is dictated by the natural history of the disease. Although advocates of nonsurgical management have proposed continuous cervical traction and total spinal column bracing in patients with severe deficits since birth and have noted improvement in ventilator and motor functions, they too hypothesized that surgical intervention might be needed later. ${ }^{20,21}$ Regarding the approach to subaxial cervical spine fusion, there is a simple approach that can be followed. In cases of minimal kyphosis with no myelopathy, a short segment fusion posteriorly may suffice. However, if severe kyphosis or myelopathy is present, anterior decompression followed by a 360-degree fixation should be aimed for. ${ }^{22,23}$

One thing that is noncontroversial in this syndrome is the need for intervention. With the review of literature and our own personal experience, it is clear that the stage of intervention matters. ${ }^{5}$ Patients who were operated earlier or at a stage where they had minimal to no deficits fared much better than those allowed to deteriorate. Further the impact of multiple falls or chronic cord compression cannot be overstated. In severe cases with apnea and respiratory distress, an even earlier decompression with Halo stabilization followed by the earliest allowable opportunity for fixation may be a safe alternative.

\section{Conclusion}

Larsen syndrome cases have several defects, the most severe of them being cervical kyphosis and atlantoaxial dislocation. A 360-degree decompression and fixation of the 
Table 1 Review of all cases of surgically corrected cervical kyphosis in patients of Larsen syndrome

\begin{tabular}{|c|c|c|c|c|c|c|c|}
\hline Author & $\begin{array}{l}\text { Age at } \\
\text { first } \\
\text { surgery }\end{array}$ & Trauma & $\begin{array}{l}\text { Traction/ } \\
\text { Collar }\end{array}$ & $\begin{array}{l}\text { Preoperative } \\
\text { condition }\end{array}$ & Surgery & $\begin{array}{l}\text { Collarl } \\
\text { brace }\end{array}$ & Follow-up \\
\hline $\begin{array}{l}\text { Micheli } \\
\text { et al } 1976^{15}\end{array}$ & $10 \mathrm{mo}$ & None & $\begin{array}{l}\text { Semirigid } \\
\text { cervical }\end{array}$ & $\begin{array}{l}\text { UE and mild LE weak- } \\
\text { ness }\end{array}$ & C3-T2 posterior fusion & $\begin{array}{l}\text { Minerva } \\
\text { jacket }\end{array}$ & Unknown \\
\hline $\begin{array}{l}\text { Muzumdar et } \\
\text { al } 1977^{21}\end{array}$ & $13.5 y$ & Fall & NA & $\begin{array}{l}\text { Bilateral numbness, } \\
\text { weakness in all four }\end{array}$ & Cervical decompression & NA & $\begin{array}{l}\text { Minimal } \\
\text { improve- } \\
\text { ment, later } \\
\text { deteriorated }\end{array}$ \\
\hline $\begin{array}{l}\text { Bowen et al } \\
1985^{5}\end{array}$ & $19 y$ & None & NA & $\begin{array}{l}\text { No deficit, progression } \\
\text { of kyphosis }\end{array}$ & $\begin{array}{l}\text { Occiput-C4 posterior } \\
\text { fusion, later scoliosis } \\
\text { correction }\end{array}$ & $\begin{array}{l}\text { Minerva } \\
\text { jacket }\end{array}$ & No deficit \\
\hline $\begin{array}{l}\text { Miz and } \\
\text { Engler } 1987^{20}\end{array}$ & $14 \mathrm{mo}$ & $\begin{array}{l}\text { Motor } \\
\text { vehicle } \\
\text { accident }\end{array}$ & NA & $\begin{array}{l}\text { Hyperreflexia, } \\
\text { decreased perineal } \\
\text { sensation }\end{array}$ & $\begin{array}{l}\text { Occiput-C2 posterior } \\
\text { fusion }\end{array}$ & $\begin{array}{l}\text { Minerva } \\
\text { jacket }\end{array}$ & $\begin{array}{l}\text { No recur- } \\
\text { rence }\end{array}$ \\
\hline $\begin{array}{l}\text { Francis and } \\
\text { Noble } 1988^{7}\end{array}$ & $5 y$ & None & NA & $\begin{array}{l}\text { Weakness, inability to } \\
\text { right self }\end{array}$ & $\begin{array}{l}\text { Anterior cervical } \\
\text { decompression, fibular } \\
\text { strut placement }\end{array}$ & Halo vest & No deficit \\
\hline $\begin{array}{l}\text { Forsee et al } \\
1995^{6}\end{array}$ & $5 y$ & None & NA & Arm weakness & $\begin{array}{l}\text { Anterior, later posterior } \\
\text { fusion }\end{array}$ & NA & $\begin{array}{l}\text { No improve- } \\
\text { ment }\end{array}$ \\
\hline \multirow[t]{5}{*}{$\begin{array}{l}\text { Johnston } \\
\text { et al } 1996^{10}\end{array}$} & $10 \mathrm{mo}$ & $\begin{array}{l}\text { Fall after } \\
\text { first oper- } \\
\text { ation }\end{array}$ & NA & $\begin{array}{l}\text { No deficit initially, fall } \\
\text { after first operation } \\
\text { induced quadriparesis }\end{array}$ & $\begin{array}{l}\text { Posterior cervical fusion } \\
\text { f/b } 2 \text { anterior decom- } \\
\text { pression and fusion }\end{array}$ & $\begin{array}{l}\text { Minerva } \\
\text { jacket and } \\
\text { Halo vest }\end{array}$ & $\begin{array}{l}\text { Improvement } \\
\text { in walking }\end{array}$ \\
\hline & $14 \mathrm{mo}$ & None & NA & No deficit & Posterior fusion & Halo vest & No deficit \\
\hline & $14 \mathrm{mo}$ & None & NA & No deficit & Posterior fusion & $\begin{array}{l}\text { Minerva } \\
\text { jacket }\end{array}$ & No deficit \\
\hline & $16 \mathrm{mo}$ & None & NA & No deficit & Posterior fusion & $\begin{array}{l}\text { Minerva } \\
\text { jacket }\end{array}$ & No deficit \\
\hline & $12 \mathrm{y}$ & None & NA & Myelopathy, weakness & $\begin{array}{l}\text { Anterior and posterior } \\
\text { fusion }\end{array}$ & NA & $\begin{array}{l}\text { No improve- } \\
\text { ment }\end{array}$ \\
\hline \multirow[t]{2}{*}{$\begin{array}{l}\text { Luk and Yip } \\
2002^{13}\end{array}$} & $8 y$ & None & NA & $\begin{array}{l}\text { No deficit at first } \\
\text { surgery, sensory in UE } \\
\text { later }\end{array}$ & $\begin{array}{l}\text { Anterior T12-L3 fusion, } \\
\text { anterior decompression } \\
\text { and fusion, later poste- } \\
\text { rior fusion }\end{array}$ & Halo vest & $\begin{array}{l}\text { Transient } \\
\text { weakness, } \\
\text { later no } \\
\text { deficit }\end{array}$ \\
\hline & $6 y$ & None & Halo & Myelopathy & $\begin{array}{l}\text { Posterior C1-T1 fusion, } \\
\text { anterior cervical fusion } \\
\text { and repeated anterior } \\
\text { fusion }\end{array}$ & Halo vest & $\begin{array}{l}\text { Myelopathy } \\
\text { resolved } \\
\text { after first } \\
\text { anterior cer } \\
\text { vical fusion }\end{array}$ \\
\hline $\begin{array}{l}\text { Banks et al } \\
2003^{1}\end{array}$ & $13 y$ & Fall & Halo & $\begin{array}{l}\text { Myelopathy, weakness } \\
\text { in all extremities }\end{array}$ & $\begin{array}{l}\text { Posterior C1-T1 fusion, } \\
\text { anterior cervical de- } \\
\text { compression and fusion } \\
4 \text { d later }\end{array}$ & $\begin{array}{l}\text { Halo vest } \\
\text { and then } \\
\text { hard cervi- } \\
\text { cal collar }\end{array}$ & $\begin{array}{l}\text { Transient } \\
\text { increased } \\
\text { weakness } \\
\text { postop w/ } \\
\text { later im- } \\
\text { provement in } \\
\text { better than } \\
\text { preop status }\end{array}$ \\
\hline $\begin{array}{l}\text { Katz et al } \\
2005^{11}\end{array}$ & $3 y$ & Falls & NA & $\begin{array}{l}\text { Weakness before first } \\
\text { operation, inability } \\
\text { to walk before third } \\
\text { operation }\end{array}$ & $\begin{array}{l}\text { Two failed posterior } \\
\text { cervical fusions, poste- } \\
\text { rior decompression and } \\
\text { fusion, later anterior } \\
\text { fusion w/ post sublami- } \\
\text { nar wires }\end{array}$ & $\begin{array}{l}\text { Halo vest } \\
\text { and then } \\
\text { collar after } \\
\text { second } \\
\text { operation, } \\
\text { Halo vest } \\
\text { through } \\
\text { fourth } \\
\text { operation, } \\
\text { later collar }\end{array}$ & $\begin{array}{l}\text { After fourth } \\
\text { operation, } \\
\text { transient } \\
\text { weakness w/ } \\
\text { improvement } \\
\text { but persis- } \\
\text { tent C5 and } \\
\text { C6 weakness }\end{array}$ \\
\hline
\end{tabular}

(continued) 
Table 1 (continued)

\begin{tabular}{|c|c|c|c|c|c|c|c|}
\hline Author & $\begin{array}{l}\text { Age at } \\
\text { first } \\
\text { surgery }\end{array}$ & Trauma & $\begin{array}{l}\text { Traction/ } \\
\text { Collar }\end{array}$ & $\begin{array}{l}\text { Preoperative } \\
\text { condition }\end{array}$ & Surgery & $\begin{array}{l}\text { Collarl } \\
\text { brace }\end{array}$ & Follow-up \\
\hline \multirow[t]{3}{*}{$\begin{array}{l}\text { Sakaura et al } \\
2007^{18}\end{array}$} & $34 \mathrm{mo}$ & None & $\begin{array}{l}\text { Minerva } \\
\text { Brace }\end{array}$ & $\begin{array}{l}\text { Spastic quadriparesis } \\
\text { with sleep apnea }\end{array}$ & $\begin{array}{l}\text { Anterior decompres- } \\
\text { sion corpectomies } \\
\text { C4-C5 arthrodesis } \\
\text { C3-C6 using tibial strut } \\
\text { bone grafts via a lateral } \\
\text { approach and later revi- } \\
\text { sion of anterior fixation } \\
\text { with C2-C7 fixation }\end{array}$ & NA & $\begin{array}{l}\text { Quadripa- } \\
\text { resis and } \\
\text { respiratory } \\
\text { dysfunction } \\
\text { improved }\end{array}$ \\
\hline & $58 \mathrm{mo}$ & None & None & Hyperreflexia & Posterior fusion C3-C5 & Halo vest & No deficit \\
\hline & $10 \mathrm{mo}$ & None & $\begin{array}{l}\text { Halo trac- } \\
\text { tion }\end{array}$ & $\begin{array}{l}\text { No deficit, kyphosis } \\
\text { worsening }\end{array}$ & $\begin{array}{l}\text { Postcervical arthrode- } \\
\text { sis. At } 29 \text { mo: Anterior } \\
\text { decompression C4-5 } \\
\text { corpectomy, C3-C6 } \\
\text { arthrodesis and later } \\
\text { occiput-T4 arthrodesis }\end{array}$ & Halo vest & No deficit \\
\hline $\begin{array}{l}\text { Madera et al } \\
2008^{14}\end{array}$ & $2.5 y$ & None & Hard collar & No deficit & $\begin{array}{l}\text { Synchronous ant } \\
\text { decompression } \\
\text { and fusion/fixation, } \\
\text { posterior fusion/fix- } \\
\text { ation }\end{array}$ & Halo vest & $\begin{array}{l}\text { Transient } \\
\text { postopera- } \\
\text { tive weakness } \\
\text { and Horner } \\
\text { syndrome } \\
\text { resolved. }\end{array}$ \\
\hline $\begin{array}{l}\text { Kumar et al } \\
2013^{16}\end{array}$ & $36 y$ & None & NA & $\begin{array}{l}\text { Mild spasticity of all } \\
\text { four limbs }\end{array}$ & $\begin{array}{l}\text { Anterior } \mathrm{C} 2-\mathrm{C} 5 \\
\text { decompression and } \\
\text { fixation and later poste- } \\
\text { rior } \mathrm{C} 1-\mathrm{C} 6 \text { fusion }\end{array}$ & $\begin{array}{l}\text { Philadel- } \\
\text { phia collar }\end{array}$ & No deficit \\
\hline $\begin{array}{l}\text { Yonekura } \\
\text { et al } 2015^{22}\end{array}$ & $18 y$ & None & NA & $\begin{array}{l}\text { Airway obstruction and } \\
\text { repeated aspiration } \\
\text { pneumonia }\end{array}$ & $\begin{array}{l}3 \text { y age: post cervical } \\
\text { arthrodesis. } 18 \text { y: } \\
\text { Anterior mediastinal } \\
\text { tracheostomy }\end{array}$ & NA & No deficit \\
\hline $\begin{array}{l}\text { Sahoo et al } \\
2016^{17}\end{array}$ & $56 y$ & None & NA & $\begin{array}{l}\text { Neck pain with spastic } \\
\text { quadriparesis }\end{array}$ & Posterior C1-C2 fusion & NA & $\begin{array}{l}\text { Improvement } \\
\text { in spasticity }\end{array}$ \\
\hline Present case & $15 y$ & None & $\begin{array}{l}\text { Hard cervi- } \\
\text { cal collar }\end{array}$ & $\begin{array}{l}\text { Neck pain with spastic } \\
\text { quadriparesis }\end{array}$ & $\begin{array}{l}\text { Transoral decompres- } \\
\text { sion f/b occipito-T1 } \\
\text { fusion }\end{array}$ & $\begin{array}{l}\text { Hard cervi- } \\
\text { cal collar }\end{array}$ & $\begin{array}{l}\text { Improvement } \\
\text { in power and } \\
\text { spasticity }\end{array}$ \\
\hline
\end{tabular}

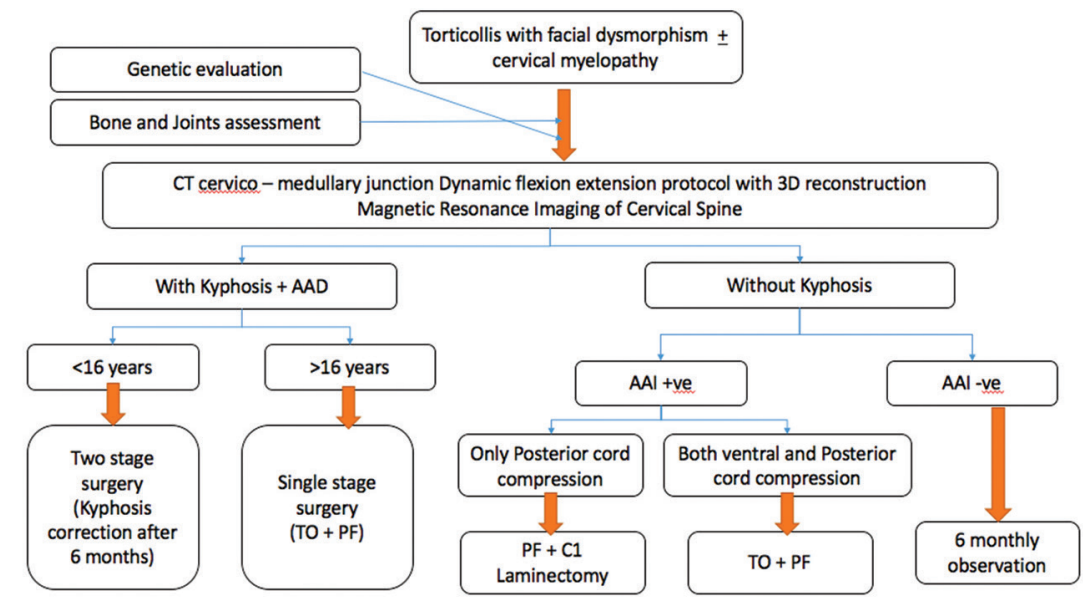

Fig. 4 Algorithmic approach to a case of Larsen syndrome. AAD, atlantoaxial dislocation; CT, computed tomography; PF, posterior fixation

atlantoaxial dislocation followed by deformity correction can prevent further deterioration due to chronic cord compression or trivial falls. We attempt to delineate here that anterior decompression at every level may not be necessary and a single posterior fusion is sufficient. Decompression anteriorly is only needed in case of significant soft tissue compression 
that otherwise cannot be addressed posteriorly. Neurological condition at presentation dictates outcome.

\section{Funding}

None.

\section{Conflict of Interest}

None declared.

\section{References}

1 Banks JT, Wellons JC III, Tubbs RS, Blount JP, Oakes WJ, Grabb PA. Cervical spine involvement in Larsen's syndrome: a case illustration. Pediatrics 2003;111(1):199-201

2 Behari S, Bhargava V, Nayak S, et al. Congenital reducible atlantoaxial dislocation: classification and surgical considerations. Acta Neurochir (Wien) 2002;144(11):1165-1177

3 Behari S, Kiran Kumar MV, Banerji D, Chhabra DK, Jain VK. Atlantoaxial dislocation associated with the maldevelopment of the posterior neural arch of axis causing compressive myelopathy. Neurol India 2004;52(4):489-491

4 Bicknell LS, Farrington-Rock C, Shafeghati Y, et al. A molecular and clinical study of Larsen syndrome caused by mutations in FLNB. J Med Genet 2007;44(2):89-98

5 Bowen JR, Ortega K, Ray S, MacEwen GD. Spinal deformities in Larsen's syndrome. Clin Orthop Relat Res 1985;(197):159-163

6 Forese LL, Berdon WE, Harcke HT, et al. Severe mid-cervical kyphosis with cord compression in Larsen's syndrome and diastrophic dysplasia: unrelated syndromes with similar radiologic findings and neurosurgical implications. Pediatr Radiol 1995;25(2):136-139

7 Francis WR Jr, Noble DP. Treatment of cervical kyphosis in children. Spine 1988;13(8):883-887

8 Jain VK, Behari S. Management of congenital atlanto-axial dislocation: some lessons learnt. Neurol India 2002;50(4):386-397

9 Jain VK, Behari S, Banerji D, Bhargava V, Chhabra DK. Transoral decompression for craniovertebral osseous anomalies: perioperative management dilemmas. Neurol India 1999;47(3):188-195

10 Johnston CE II, Birch JG, Daniels JL. Cervical kyphosis in patients who have Larsen syndrome. J Bone Joint Surg Am 1996;78(4):538-545
11 Katz DA, Hall JE, Emans JB. Cervical kyphosis associated with anteroposterior dissociation and quadriparesis in Larsen's syndrome. J Pediatr Orthop 2005;25(4):429-433

12 Larsen LJ, Schottstaedt ER, Bost FC. Multiple congenital dislocations associated with characteristic facial abnormality.J Pediatr 1950;37(4):574-581

13 Luk KD, Yip DK. Congenital anteroposterior spinal dissociation in Larsen's syndrome: report on two operated cases with long-term follow-up. Spine 2002;27(12):E296-E300

14 Madera M, Crawford A, Mangano FT. Management of severe cervical kyphosis in a patient with Larsen syndrome. Case report. J Neurosurg Pediatr 2008;1(4):320-324

15 Micheli LJ, Hall JE, Watts HG. Spinal instability in Larsen's syndrome: report of three cases. J Bone Joint Surg Am 1976;58(4):562-565

16 Roopesh Kumar VR, Madhguiri VS, Sasidharan GM, Gundamaneni SK, Yadav AK. Larsen syndrome with C3-C4 spondyloptosis and atlantoaxial dislocation in an adult. Spine 2013;38(1):E43-E47

17 Sahoo SK, Deepak AN, Salunke P. Atlantoaxial dislocation adjacent to kyphotic deformity in a case of adult Larsen syndrome. J Craniovertebr Junction Spine 2016;7(2):109-110

18 Sakaura H, Matsuoka T, Iwasaki M, Yonenobu K, Yoshikawa H. Surgical treatment of cervical kyphosis in Larsen syndrome: report of 3 cases and review of the literature. Spine 2007;32(1):E39-E44

19 Sardhara J, Behari S, Jaiswal AK, et al. Syndromic versus nonsyndromic atlantoaxial dislocation: do clinico-radiological differences have a bearing on management? Acta Neurochir (Wien) 2013;155(7):1157-1167

20 Miz GS, Engler GL. Atlanto-axial subluxation in Larsen's syndrome. A case report. Spine 1987;12(4):411-412

21 Muzumdar AS, Lowry RB, Robinson CE. Quadriplegia in Larsen syndrome. Birth Defects Orig Artic Ser 1977;13(3C) :202-211

22 Yonekura T, Kamiyama M, Kimura K, et al. Anterior mediastinal tracheostomy with a median mandibular splitting approach in a Larsen syndrome patient with posterior cervical arthrodesis. Pediatr Surg Int 2015;31(10):1001-1004

23 Martus JE, Griffith TE, Dear JC, Rathjen KE. Pediatric cervical kyphosis: a comparison of arthrodesis techniques. Spine 2011;36(17):E1145-E1153 